\title{
Effects of a High-Protein/Moderate-Carbohydrate Diet on Appetite, Gut Peptides, and Endocannabinoids-A Preview Study
}

\author{
Lea Tischmann ${ }^{1,2, *,+}{ }^{(}$, Mathijs Drummen ${ }^{1,2,+}$, Blandine Gatta-Cherifi ${ }^{3,4,5}$, Anne Raben ${ }^{6}{ }^{\circledR}$, \\ Mikael Fogelholm ${ }^{7}\left(\mathbb{D}\right.$, Bolette Hartmann ${ }^{8}\left(\mathbb{D}\right.$, Jens J. Holst ${ }^{8}\left(\mathbb{D}\right.$, Isabelle Matias ${ }^{4,5}$, \\ Daniela Cota ${ }^{4,5}$, Ronald P. Mensink ${ }^{1,2}$, Peter J. Joris ${ }^{1,2} \mathbb{D}$, Margriet S. Westerterp-Plantenga ${ }^{2}(\mathbb{D})$ \\ and Tanja C. Adam 1,2 \\ 1 Department of Nutrition and Movement Sciences, Maastricht University Medical Centre, 6200 MD \\ Maastricht, The Netherlands; m.drummen@maastrichtuniversity.nl (M.D.); \\ r.mensink@maastrichtuniversity.nl (R.P.M.); p.joris@maastrichtuniversity.nl (P.J.J.); \\ t.adam@maastrichtuniversity.nl (T.C.A.) \\ 2 NUTRIM School of Nutrition and Translational Research in Metabolism, Maastricht University, \\ 6200 MD Maastricht, The Netherlands; m.westerterp@maastrichtuniversity.nl \\ 3 Department of Endocrinology, University Hospital of Bordeaux, F-33607 Pessac, France; \\ blandine.gatta-cherifi@chu-bordeaux.fr \\ 4 INSERM, Neurocentre Magendie, Physiopathologie de la Plasticité Neuronale, U1215, \\ F-33000 Bordeaux, France; isabelle.matias@inserm.fr (I.M.); daniela.cota@inserm.fr (D.C.) \\ 5 University of Bordeaux, Neurocentre Magendie, Physiopathologie de la Plasticité Neuronale, U1215, \\ F-33000 Bordeaux, France \\ 6 Department of Nutrition, Exercise and Sports, University of Copenhagen, DK1017 Copenhagen, Denmark; \\ ara@nexs.ku.dk \\ 7 Department of Food and Environmental Sciences, University of Helsinki, FI-00014 Helsinki, Finland; \\ mikael.fogelholm@helsinki.fi \\ 8 NNF Center of Basic Metabolic Research and Department of Biomedical Sciences, University of Copenhagen, \\ 2200 Copenhagen, Denmark; bhartmann@sund.ku.dk (B.H.); jjholst@sund.ku.dk (J.J.H.) \\ * Correspondence: 1.tischmann@maastrichtuniversity.nl; Tel.: +31-43-388-4596 \\ + Both authors contributed equally to the paper.
}

Received: 15 August 2019; Accepted: 19 September 2019; Published: 21 September 2019

check for updates

\begin{abstract}
Favorable effects of a high-protein/moderate-carbohydrate (HP/MCHO) diet after weight loss on body weight management have been shown. To extend these findings, associations between perception of hunger and satiety with endocannabinoids, and with glucagon-like peptide-1 (GLP-1) and polypeptide YY (PYY) were assessed. At approximately 34 months after weight loss, 22 female and 16 male participants (mean age $64.5 \pm 5.9$ years; body mass index (BMI) $28.9 \pm 3.9 \mathrm{~kg} / \mathrm{m}^{2}$ ) completed a $48 \mathrm{~h}$ respiration chamber study. Participants were fed in energy balance with a HP/MCHO diet with 25\%:45\%:30\% or a moderate-protein/high-carbohydrate (MP/HCHO) diet with 15\%:55\%:30\% of energy from protein:carbohydrate:fat. Endocannabinoids and related compounds, relevant postprandial hormones (GLP-1, PYY), hunger, satiety, and ad libitum food intake were assessed. HP/MCHO versus $\mathrm{MP} / \mathrm{HCHO}$ reduced hunger perception. The lower decremental area under the curve (dAUC) for hunger in the $\mathrm{HP} / \mathrm{MCHO}$ diet $(-56.6 \%$ compared to $\mathrm{MP}, p<0.05)$ was associated with the higher AUC for 2-arachidonoylglycerol (2-AG) concentrations $(p<0.05)$. Hunger was inversely associated with PYY in the HP/MCHO group $(\mathrm{r}=-0.7, p<0.01)$. Ad libitum food intake, homeostatic model assessment for insulin resistance (HOMA-IR) and incremental AUCs for gut peptides were not different between conditions. $\mathrm{HP} / \mathrm{MCHO}$ versus $\mathrm{MP} / \mathrm{HCHO}$ diet-induced reduction in hunger was present after 34 months weight maintenance in the post-obese state. HP/MCHO diet-induced decrease of hunger is suggested to interact with increased 2-AG and PYY concentrations.
\end{abstract}


Keywords: Protein; endocannabinoids; hunger; satiety; gut peptides; weight maintenance; obesity

\section{Introduction}

In $2016,39 \%$ of the adult population worldwide was considered overweight and $13 \%$ obese [1]. A positive energy balance is one of the most critical underpinnings for this development, posing a major risk for the development of chronic diseases including type-II diabetes (T2D) and cardiovascular disease [2].

While successful dieting and weight maintenance are essential to long-term improvements of metabolic disease, weight maintenance remains especially challenging. For weight reduction as well as long-term weight maintenance, dietary protein was suggested as being potentially helpful due to the notion that it appears to be more satiating than carbohydrates or fat in an acute setting [3-7], and therefore may support the reduction of food intake [8]. Additionally, a ketogenic state, induced by a short- or medium-term high-protein, low-carbohydrate condition $[9,10]$, has been suggested as a contributor to protein-related appetite regulation. In addition to increased satiety, protein was shown to have sparing effects on fat-free mass (FFM) during weight reduction and weight maintenance [11,12], while energy expenditure increased $[5,11,13,14]$.

The endocannabinoid system is critically involved in the regulation of energy balance and in the pathophysiology of metabolic disorders [15-17]. The system comprises endogenous lipids, the cannabinoid receptor 1 and 2 (CB1 and CB2) and the enzymatic machinery involved in the synthesis and degradation of endocannabinoids [15]. The best characterized endocannabinoids are the $\mathrm{N}$-ethanolamide of arachidonic acids, known as anandamide (AEA) and the glycerol ester of arachidonic acid or 2-AG. The lipid derivatives and endocannabinoid-related compounds oleoylethanolamide (OEA) and palmitoylethanolamide (PEA) are synthetized together with AEA and share structural similarities, but do not bind to cannabinoid receptors. AEA and 2-AG both correlate positively with markers of obesity and metabolic disorders in humans [18-20]. OEA decreases appetite and favors weight loss and lipolysis by acting through peroxisome proliferator-activated receptor- $\alpha$ (PPAR- $\alpha$ ), contrasting the metabolic effects of the endocannabinoid-dependent CB1 receptor activation [21], which has been linked to obesity promotion [17]. Pregnenolone (PREG), a neurosteroid precursor, has been suggested to be a negative regulator of endocannabinoids by experimental data [22] and thereby prevents overstimulation of the cannabinoid receptor [22]. While endocannabinoids have been assessed with regard to energy balance $[17,23]$ and fat intake [20], the role of dietary protein in endocannabinoid signaling remains unknown.

In addition, satiety-related gut peptides such as GLP-1 and PYY, have been reported to be increased $[24,25]$ in response to high-protein intake compared to high-carbohydrate or high-fat intake. Both GLP-1 and PYY have incidentally been linked to increased satiety and reduced food intake [26]. However, based on the literature, individual perception of appetite and appetite-related gut peptides was not consistently associated [27]. Therefore, the use of gut peptides as a direct biomarker for perceived appetite alone appears insufficient [28].

The present study aimed to assess the effects of a high-protein/moderate-carbohydrate (HP/MCHO) versus moderate-protein/high-carbohydrate $(\mathrm{MP} / \mathrm{HCHO})$ diet in the post-obese state after weight loss, on the association between perception and physiology of hunger and satiety in energy balance, in a controlled respiration chamber setting. Especially, the protein-content-related differences in concentrations of endocannabinoids and related compounds as well as their potential association with hunger and satiety perception were assessed. We hypothesized that also in the post-obese phase, a high-protein/moderate-carbohydrate diet would be more satiating compared to a moderate-protein/high-carbohydrate diet, evidenced by higher satiety ratings and lower hunger ratings, possibly associated with changes in concentrations of endocannabinoids and related compounds, and with increased satiety hormone concentrations. 


\section{Materials and Methods}

The study was registered at ClinicalTrials.gov (NCT01777893), was performed in line with the Declaration of Helsinki, and was approved by the Medical Research Ethics Committee of Maastricht University Medical Centre (METC). All participants provided written informed consent for participation. The study was performed at Maastricht University from February 2017 until February 2018.

\subsection{Participants}

A subgroup of 40 participants was recruited from the PREVention of diabetes through lifestyle intervention and population studies in Europe and around the World (PREVIEW) cohort [29] at Maastricht University in the Netherlands, of which 2 dropped out due to a lack of time (Supplementary Figure S1). Sample size calculation was based on energy expenditure [30]. The PREVIEW intervention study (Prevention of Diabetes through lifestyle intervention and population studies in Europe and around the World, EU seventh Framework Program, grant agreement no. 31205) is a multinational, multicenter, $2 \times 2$ factorial, randomized controlled trial aimed at finding the most effective lifestyle intervention to prevent the development of T2D in predisposed individuals. Individuals were between 25 and 70 years of age and had a Body Mass Index (BMI) above $25 \mathrm{~kg} / \mathrm{m}^{2}$. Pre-diabetes, which was defined by a fasting plasma glucose concentration between 5.6 and $6.9 \mathrm{mmol} / \mathrm{L}$ and/or a $2 \mathrm{~h}$ plasma glucose between 7.8 and $11.0 \mathrm{mmol} / \mathrm{L}$ following an oral glucose tolerance test (OGTT) [29], was an inclusion criterion for participation. Exclusion criteria for this respiration chamber sub-study were claustrophobia, smoking, and previous cardiovascular events, next to the exclusion criteria for the PREVIEW study [29]. Written informed consent was obtained from all participants before starting the experiment.

\subsection{Experimental Design}

Detailed information on the PREVIEW intervention study design, interventions, subject recruitment, primary and secondary endpoints, and baseline characteristics have been published before [29]. In short, an 8 week weight-reduction period by means of a low-energy diet was followed by 34 months of a randomized intervention comprising four treatment groups: $\mathrm{MP} / \mathrm{HCHO}$ with moderate-glycemic index (GI), or a HP/MCHO diet with low-GI, combined with either moderate- or high-intensity physical activity in a parallel design. In close proximity to the last clinical investigation day (after 34 months) of the PREVIEW intervention, a subgroup of participants underwent a $48 \mathrm{~h}$ experiment in the respiration chamber to assess specific $\mathrm{HP} / \mathrm{MCHO}$ intake-related aspects of hunger and satiety regulation. Participants arrived at the Metabolic Research Unit Maastricht (MRUM) research facilities in the morning after an overnight fast from 22:00 $\mathrm{h}$ the night before. The respiration chamber experiment started at 9:30 h. Participants had fixed bedtimes in the respiration chambers from 11:30 $\mathrm{h}$ until 7:30 $\mathrm{h}$ and were not allowed to sleep during the daytime or to exercise.

\subsection{Anthropometric Measurements}

Body weight and body composition (BOD POD ${ }^{\circledR}$, Life Measurement Inc., Concord, CA, USA) were measured before the respiration chamber experiment was started. Height was measured using a wall-mounted stadiometer during screening.

\subsection{Respiration Chamber}

The respiration chambers are $14 \mathrm{~m}^{3}$ airtight rooms with a controlled climate and furnished with a bed, chair, table, intercom, TV, computer, sink, and toilet. Continuous fresh air ventilation at a rate of 70-80 L/min was used and measured with a dry gas meter (G6, gasmeterfabriek Schlumberger, Dordrecht, the Netherlands). $\mathrm{O}_{2}$ and $\mathrm{CO}_{2}$ concentrations were continuously measured by open-circuit ventilated indirect calorimetry, using dual pairs of infrared $\mathrm{CO}_{2}$ analyzer (ABB/Hartman and Braun Uras, Frankfurt a.M., Germany) and paramagnetic $\mathrm{O}_{2}$ analyzers (Servomex 4100, Crowborough, England 
and ABB/Hartman and Braun Magnos, Frankfurt a.M., Germany) [31]. Total energy expenditure (EE) was calculated according to the formula of Weir [32].

\subsection{Diets and Energy Intake}

Participants received either a MP/HCHO (15\%:55\%:30\% of energy from protein:carbohydrate:fat) or a $\mathrm{HP} / \mathrm{MCHO}$ (25\%:45\%:30\% of energy from protein:carbohydrate:fat) diet, according to their previous intervention group during the PREVIEW study. To keep menus as comparable as possible, the basis of all meals was the same between groups, combined with either carbohydrate- or protein-rich food items. Participants were asked to pay special attention to their prescribed study diet during the week before the experiment. All meals were provided in energy balance according to individual energy requirements during the respiration chamber session. The daily energy requirement was estimated by calculating the basal metabolic rate (BMR) with the use of fat mass (FM) and fat-free mass (FFM), which was then multiplied by a physical activity index of 1.35 , based on previous respiration chamber experiments [33]. Dietary intake was divided over three meals with $20 \%$ of the daily energy requirement for breakfast (at 9:15 h) and 40\% for both lunch (at 13:00 h) and dinner (at 17:45 h). No other food products were allowed for consumption. Water consumption was allowed throughout the study at the participants' convenience and unsweetened coffee or tea were served at several time points. For the ad libitum brunch after the $48 \mathrm{~h}$ in the respiration chamber, participants received a buffet style meal. This meal was the same for the two intervention groups and comparable to the chamber breakfast from the days before, but not diet-specific and including choices of carbohydrate- or protein-rich options. Total energy and macronutrient intake were evaluated afterwards.

\subsection{Appetite Profile}

Subjective perception of appetite comprising hunger, fullness, and satiety was measured by $100 \mathrm{~mm}$ anchored visual analogue scales (VAS) from "not at all" to "very" during day 2 in the respiration chamber [34]. Questionnaires were scored before and $30 \mathrm{~min}$ after each meal, as well as once in between the meals. In the case of a simultaneous blood draw, questionnaires were done before the blood draw. The incremental area under the curve (iAUC) was calculated for satiety and fullness perception, and the dAUC was calculated for hunger perception using the trapezoidal rule [35].

\subsection{Metabolic Parameters}

Fasting blood samples were taken from an antecubital vein by venipuncture on the first and last day of the respiration chamber study for the analysis of fasting glucose, insulin, $\beta$-hydroxybutyrate, and triacylglycerol. On the second day, a venflon catheter (Becton, Dickinson and Company, Franklin Lanes, NY, USA) was placed in the antecubital vein for fasted and postprandial blood collections throughout the day for collection of endocannabinoids and related compounds, glucose, insulin, GLP-1, and PYY. Blood samples were drawn directly before and 30, 60, 90, and $120 \mathrm{~min}$ after all three meals. Except for serum samples, all samples were immediately stored on ice, centrifuged for $10 \mathrm{~min}$ at 1500 g at $4{ }^{\circ} \mathrm{C}$, immediately distributed in aliquots, and stored at $-80^{\circ} \mathrm{C}$ until analysis at the end of the study, enabling all samples from one participant to be analyzed in the same run. Serum samples were kept at room temperature for $30 \mathrm{~min}$ to allow clotting before centrifugation $\left(10 \mathrm{~min}\right.$ at $1500 \mathrm{~g}$ at $\left.4{ }^{\circ} \mathrm{C}\right)$. For endocannabinoid and related compounds measurements, samples were collected immediately before, $60 \mathrm{~min}$ after meals, and $120 \mathrm{~min}$ after dinner. The AUC was calculated for the endocannabinoids and related substances. The iAUC was calculated for GLP-1, PYY, glucose, and insulin using the trapezoidal rule [35].

\subsubsection{Endocannabinoids and Endocannabinoid-Related Compounds}

For endocannabinoid and endocannabinoid-related compound analysis, ethylenediaminetetraacetic acid (EDTA) tubes (Becton, Dickinson and Company, Franklin Lakes, NY, USA) were used. Syringes and EDTA tubes were ice-chilled before blood collection and storage cups were prepared with 
$1 \%$ phenylmethylsulfonyl fluoride (PMSF) solution (10 mg PMSF in $1 \mathrm{~mL}$ methanol) and $5 \% 1 \mathrm{~N}$ hydrochloric acid at final concentration. Samples were snap frozen in liquid nitrogen immediately.

The extraction, purification, and quantification of AEA, PEA, OEA, and 2-AG from blood require a set of different biochemical steps as described previously [19,36]. Samples were then subjected to isotope-dilution liquid chromatography-chemical ionization-tandem mass spectrometric analysis. Mass spectral analyses were performed on a TSQ Quantum Access triple quadrupole instrument (Thermo-Finnigan, San Jose, CA, USA) equipped with an APCI source (atmospheric pressure chemical ionization) and operating in positive ion mode [37]. Pregnenolone was extracted from plasma by a simple solid-phase extraction method using reverse-phase C18 columns according to the method described in Vallée et al. [22] and analyzed with a GC-MS/MS (gas chromatography-tandem mass spectrometer) XLS Ultra Thermo mass spectrometer (Thermo-Finnigan, San Jose, CA, USA) via an AS3000 II autosampler.

\subsubsection{GLP-1 and PYY}

For analyses of GLP-1 and PYY concentrations, EDTA-aprotinin tubes (Becton, Dickinson and Company, Franklin Lakes, NY, USA) with added dipeptidyl peptidase IV inhibitor ( $10 \mathrm{~mL} / \mathrm{L}$ blood) were used. Syringes and EDTA-aprotinin tubes were ice-chilled before blood collection and samples were snap frozen in liquid nitrogen immediately. Total GLP-1 [38] and PYY3-36 concentrations were both determined using a radioimmunoassay method. For the PYY assay, a 125-Iodine label was used and data were analyzed with RIACALC (Pharmacia, Freiburg, Germany).

\subsubsection{Glucose and Insulin}

Plasma for colorimetric glucose analysis (Roche Diagnostic Systems, Woerden, the Netherlands) was collected in sodium fluoride tubes (Becton, Dickinson and Company, Franklin Lakes, NY, USA). Serum for insulin analysis was collected in serum separator tubes (Becton, Dickinson and Company, Franklin Lakes, NY, USA). Samples were used to analyze fasting and postprandial insulin concentrations with a human insulin-specific radioimmunoassay (Linco Research, St Charles, MO, USA). Insulin sensitivity was estimated by calculating the HOMA-IR [39].

\subsection{4. $\beta$-Hydroxybutyrate}

EDTA vacutainer tubes (Becton, Dickinson and Company, Franklin Lakes, NY, USA) were used to collect plasma samples for $\beta$-hydroxybutyrate concentrations analysis with gas chromatography-mass spectrometry (GC-MS) quantification (Varian factor four VF- $5 \mathrm{~ms}, 15 \mathrm{mx} 0.25 \mathrm{~mm} * 0.1 \mu \mathrm{M}$ with GCMS ms 7890A-7000c, Agilent, Santa Clara, CA, USA).

\subsubsection{Triacylglycerol}

Serum samples (Becton, Dickinson and Company, Franklin Lakes, NY, USA) were used to analyze fasting triacylglycerol (GPO Trinder; Sigma-Aldrich Corp., St. Louis, MO, USA).

\subsection{Statistical Analysis}

All statistical tests were performed using SPSS for Macintosh (Version 25; SPSS Inc., Chicago, IL, USA). Data are presented as means \pm standard deviations (SDs), unless otherwise indicated. Significance was defined as $p<0.05$. Differences between both groups before and during their respiration chamber stay were calculated using ANOVA, and repeated measures ANOVA with BMI or body-fat percentage as a covariate, if appropriate. Not normally distributed data, as determined with the Shapiro-Wilk test, were log-transformed and tested on normality again. Partial correlation coefficients were calculated to assess associations between protein intake, appetite, gut peptides, and endocannabinoids, adjusted for BMI and fat percentage, if appropriate. 


\section{Results}

\subsection{Study Participants}

The subject characteristics for the $\mathrm{MP} / \mathrm{HCHO}$ and $\mathrm{HP} / \mathrm{MCHO}$ group at baseline of the respiration chamber experiment are summarized in Table 1 . Twenty participants started the respiration chamber experiment in the $\mathrm{HP} / \mathrm{MCHO}$ condition and 18 participants in the $\mathrm{MP} / \mathrm{HCHO}$ condition. The two groups were not different with regard to age, anthropometric variables, and fasting glucose and insulin concentrations prior to the respiration chamber experiment. Only triacylglycerol (TAG) was higher in the $\mathrm{MP} / \mathrm{HCHO}$ group at baseline.

Table 1. Subject characteristics of the moderate/high carbohydrate (MP/HCHO), and high-protein/ moderate-carbohydrate $(\mathrm{HP} / \mathrm{MCHO})$ group at baseline of the respiration chamber experiment.

\begin{tabular}{ccc}
\hline & MP/ HCHO $(n=\mathbf{1 8})$ & HP/MCHO $(n=\mathbf{2 0})$ \\
\hline$N(\mathrm{f} / \mathrm{m})$ & $18(9 / 9)$ & $20(13 / 7)$ \\
Age (year) & $65.1 \pm 5.8$ & $64.0 \pm 6.2$ \\
BMI $\left(\mathrm{kg} / \mathrm{m}^{2}\right)$ & $29.0 \pm 3.8$ & $28.9 \pm 4.0$ \\
Body-fat $(\%)$ & $39.5 \pm 8.1$ & $40.7 \pm 7.7$ \\
Fat mass $(\mathrm{kg})$ & $33.9 \pm 7.1$ & $34.8 \pm 8.8$ \\
Fat-free mass $(\mathrm{kg})$ & $52.5 \pm 10.9$ & $50.8 \pm 11.3$ \\
Glucose $(\mathrm{mmol} / \mathrm{L})$ & $5.8 \pm 0.4$ & $5.7 \pm 0.5$ \\
Insulin $(\mu \mathrm{U} / \mathrm{mL})$ & $14.8 \pm 7.6$ & $14.4 \pm 4.9$ \\
HOMA-IR & $3.8 \pm 1.8$ & $3.6 \pm 1.3$ \\
TAG (mmol/L) & $1.5 \pm 0.7$ & $1.2 \pm 0.6^{*}$ \\
\hline
\end{tabular}

Values are means \pm standard deviation (SD). BMI: Body Mass Index; HOMA-IR: Homeostatic Model Assessment of Insulin Resistance; TAG: triacylglycerol. ${ }^{*} p<0.05$.

\subsection{4-Hour Hunger and Satiety Perception}

Baseline appetite profile was not different between conditions. Hunger perception (VAS) based on the decremental area under the curve during the whole day was significantly lower in the HP/MCHO diet compared to the $\mathrm{MP} / \mathrm{HCHO} \operatorname{diet}(-56.6 \%, \mathrm{~F}=5.89, p<0.05$, Figure 1$)$. Looking at the individual meals, specifically breakfast $(-83 \% ; \mathrm{F}=10.30, p<0.01)$ seemed to have contributed to the overall difference between the intervention groups. The differences in hunger ratings could not be explained by differences in energy balance (MP/HCHO: $0.2 \pm 0.9$ megajoule $(\mathrm{MJ}), \mathrm{HP} / \mathrm{MCHO}:-0.5 \pm 0.9 \mathrm{MJ}$; $\mathrm{F}=6.03, p<0.05)$ [30] between the two intervention groups. There were no differences in satiety or fullness ratings between the two groups (Figure 1).

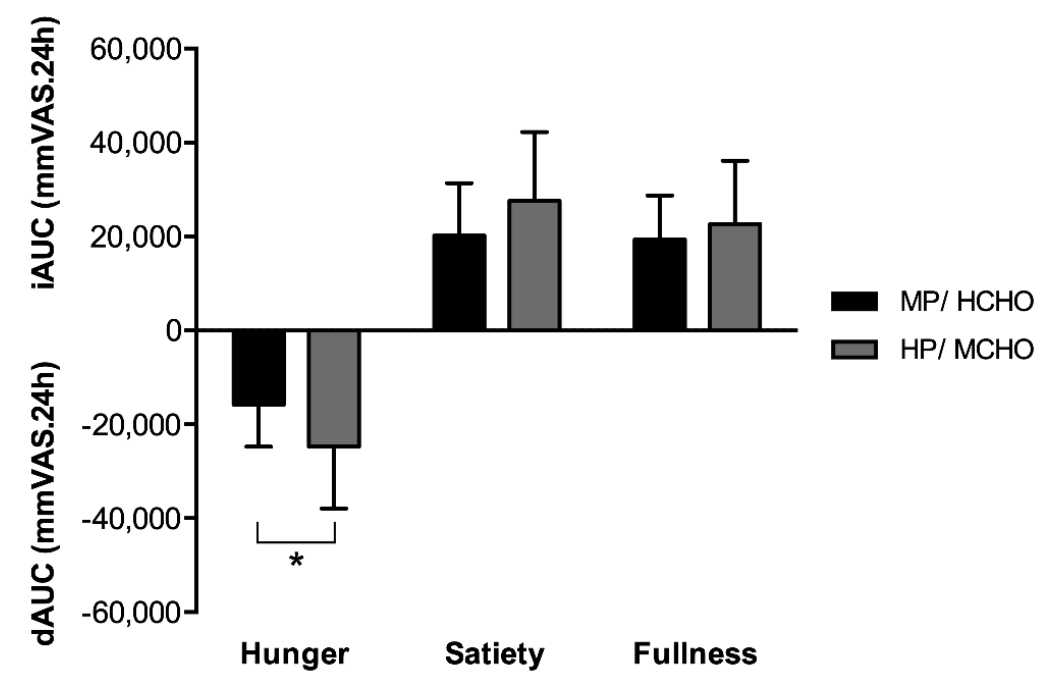


Figure 1. Visual analogue scales for appetite for $\mathrm{MP} / \mathrm{HCHO}$ (black) and $\mathrm{HP} / \mathrm{MCHO}$ (grey) groups. Hunger is presented as dAUC, fullness and satiety as iAUC. ${ }^{*} p<0.05$. Values are means \pm SD. Differences between groups were calculated with a One-Way ANOVA. MP/HCHO = moderate protein/high carbohydrate; $\mathrm{HP} / \mathrm{MCHO}=$ high protein/moderate carbohydrate; iAUC = incremental area under the curve; dAUC $=$ decremental area under the curve; mmVAS = millimeter visual analogue scale.

\subsection{Metabolic Parameters}

\subsubsection{Endocannabinoids and Related Compounds Concentrations Throughout the Day}

2-AG showed increased concentrations 60 mins after each meal, then decreasing back to baseline concentrations before the next meal (Figure 2). Around lunch, there was a significant time-by-treatment interaction for 2-AG $(\mathrm{F}=6.61, p<0.05)$. In addition, the AUC of 2-AG was significantly higher in $\mathrm{HP} / \mathrm{MCHO}$ compared to $\mathrm{MP} / \mathrm{HCHO}(4351 \pm 1616 \mathrm{pmol} / \mathrm{L}$ versus $3368 \pm 1552 \mathrm{pmol} / \mathrm{L}, \mathrm{F}=4.67, p<0.05)$ and the post-meal change in 2-AG during dinner was positively related to the change in hunger ( $r=0.37, p<0.05)$. Post-meal changes of $2-A G$ were not related to changes in glucose, insulin, GLP-1, or PYY during any of the meals or to body weight or body composition. The postprandial change in $2-A G$ after dinner was positively associated with the change in pleasantness ratings $(r=0.425, p<0.05)$. There was no clear meal associated pattern or higher protein/moderate carbohydrate intervention related effect in other endocannabinoids and related compounds. However, we observed that OEA concentrations (AUC) were inversely associated with the change in TAG (Figure 3) throughout the $48 \mathrm{~h}$ of the experiment $(\mathrm{r}=-0.40, p<0.05)$.
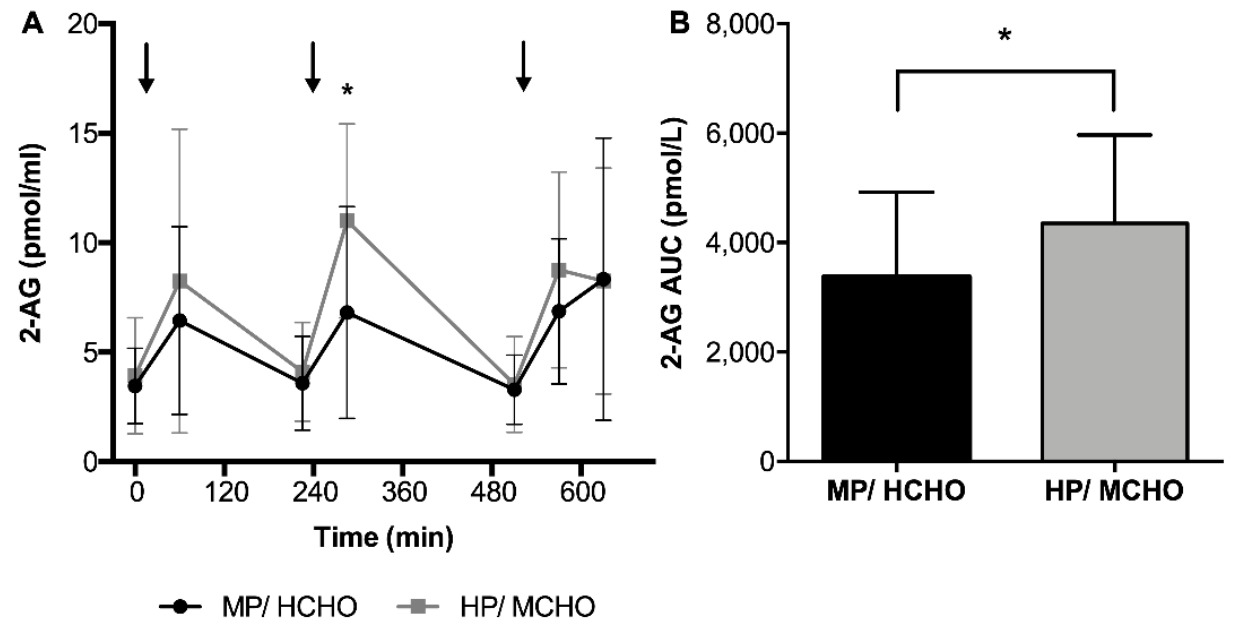

Figure 2. (A) Postprandial responses and (B) area under the curve (AUC) of 2-AG in the MP/HCHO (black) and $\mathrm{HP} / \mathrm{MCHO}$ (grey) group. Arrows indicating timepoint of meals. Values are means $\pm \mathrm{SD}$. $\mathrm{MP} / \mathrm{HCHO}=$ moderate protein/high carbohydrate; $\mathrm{HP} / \mathrm{MCHO}=$ high protein/moderate carbohydrate; 2-AG: 2-arachidonoylglycerol. * $p<0.05$. 

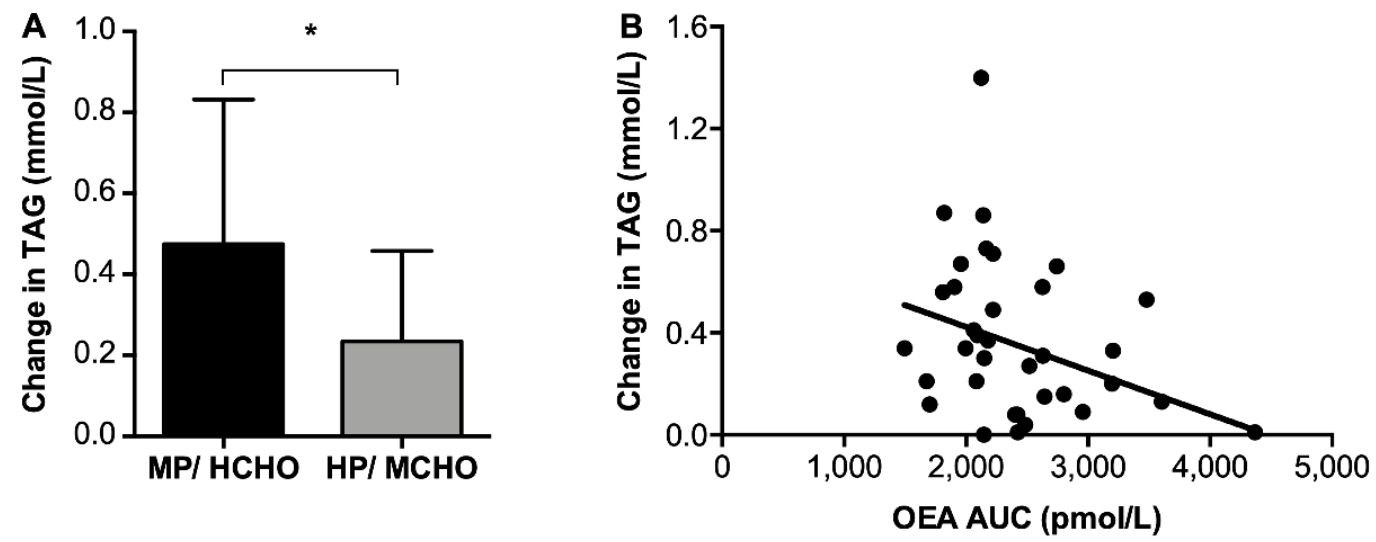

Figure 3. (A) AUC of change in TAG over $48 \mathrm{~h}$ in the $\mathrm{MP} / \mathrm{HCHO}$ (black) and $\mathrm{HP} / \mathrm{MCHO}$ (grey) group and $(B)$ inverse association of OEA concentrations throughout the day and the change in TAG over $48 \mathrm{~h}$. Values are means $\pm \mathrm{SD} . \mathrm{MP} / \mathrm{HCHO}=$ moderate protein/high carbohydrate; $\mathrm{HP} / \mathrm{MCHO}=$ high protein/moderate carbohydrate; TAG: triacylglycerol; OEA: oleoylethanolamide. ${ }^{*} p<0.05$.

\subsubsection{Gut peptides, Glucose, and Insulin Concentrations Throughout the Day}

Postprandial plasma GLP-1 and PYY concentrations are shown in Figure 4. No significant differences in GLP-1 and PYY response, expressed as iAUC, were found between the HP/MCHO and the $\mathrm{MP} / \mathrm{HCHO}$ group (Figure 4). In the complete group, the dAUC of hunger was inversely associated with the PYY iAUC $(r=0.40, p<0.05)$ however this was especially the case in the HP/MCHO group. We found a significant interaction between group and PYY iAUC with regard to hunger ratings $(\mathrm{F}=7.47, p<0.05)$. In the $\mathrm{HP} / \mathrm{MCHO}$ group, hunger (dAUC) was inversely associated with PYY (iAUC) concentrations ( $r=0.71, p<0.01$; Figure 5$)$, but not in the MP/HCHO group. GLP-1 was not associated with any of the subjective appetite assessments (hunger, fullness, and satiety). Neither PYY nor GLP-1 concentrations were associated with energy balance in any of the two intervention groups or with parameters related to glucose metabolism. Postprandial glucose concentrations were incidentally higher in the $\mathrm{MP} / \mathrm{HCHO}$ group but both, glucose and insulin concentrations throughout the day (Figure 4) did not differ between the two intervention groups. 

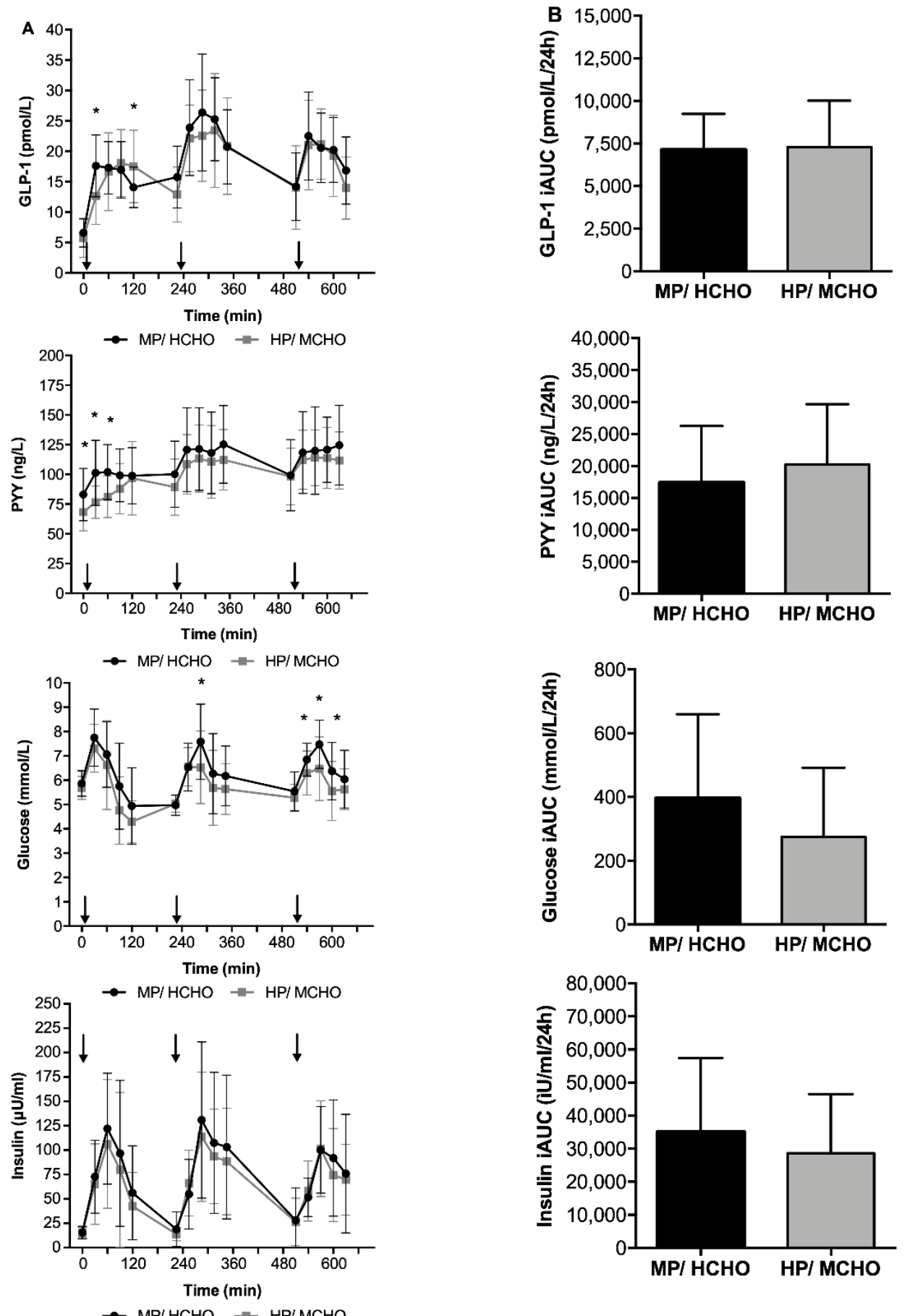

Figure 4. (A) Postprandial responses over time and (B) incremental area under the curves of GLP-1, PYY, glucose, and insulin in the $\mathrm{MP} / \mathrm{HCHO}$ (black) and $\mathrm{HP} / \mathrm{MCHO}$ (grey) group. Arrows indicating timepoint of meals. ${ }^{*} p<0.05$. Values are means \pm SD. Differences between groups were calculated with a One-Way ANOVA. $\mathrm{MP} / \mathrm{HCHO}=$ moderate protein/high carbohydrate; $\mathrm{HP} / \mathrm{MCHO}=$ high protein/moderate carbohydrate; GLP-1 = glucagon-like peptide 1; PYY = peptide YY; iAUC = incremental area under the curve. 


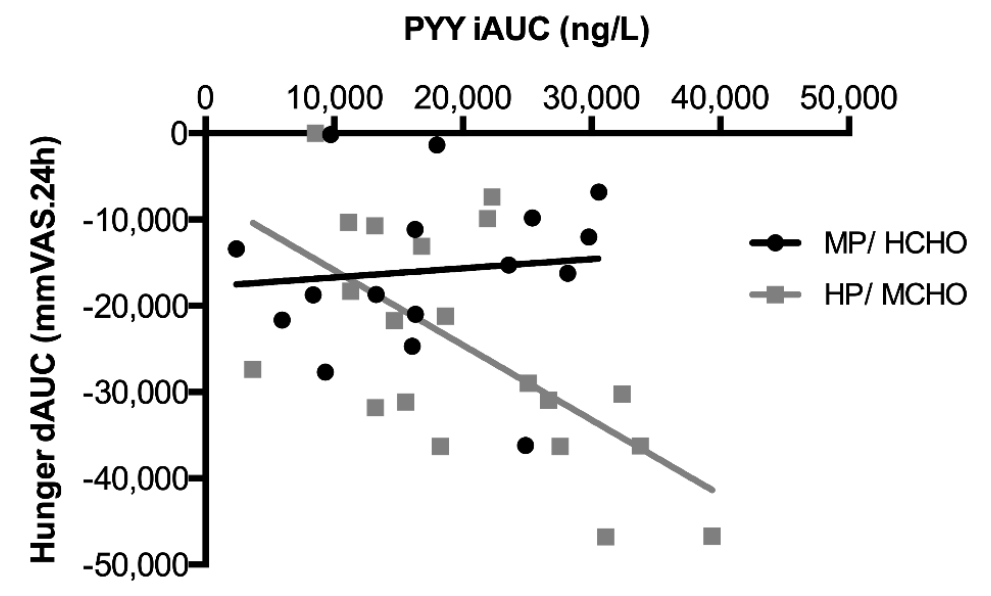

Figure 5. Inverse association of hunger and PYY concentrations throughout the day in the $\mathrm{MP} / \mathrm{HCHO}$ $(\bullet)$ and $\mathrm{HP} / \mathrm{MCHO}(\equiv)$ group. Regression lines are shown in black $(\mathrm{MP} / \mathrm{HCHO})$ and grey $(\mathrm{HP} / \mathrm{MCHO}$, $\mathrm{r}=0.710, p=0.001) . \quad \mathrm{MP} / \mathrm{HCHO}=$ moderate protein/high carbohydrate; $\mathrm{HP} / \mathrm{MCHO}=$ high protein/moderate carbohydrate; iAUC = incremental area under the curve; $\mathrm{dAUC}=$ decremental area under the curve; PYY = peptide YY.

\subsubsection{Fasted $\beta$-Hydroxybutyrate and Triacylglycerol Concentrations}

Plasma $\beta$-hydroxybutyrate concentrations, a marker for fat oxidation, were not different between dietary conditions (MP/HCHO: $90.05 \pm 87.61 \mu \mathrm{g} / \mathrm{mL}$ and HP/MCHO: $117.57 \pm 93.35 \mu \mathrm{g} / \mathrm{mL}$ ). Baseline $\beta$-hydroxybutyrate was negatively associated with BMI $(\mathrm{r}=-0.35, p<0.05)$ but was not associated with appetite perception or gut peptides. TAG concentrations increased in both intervention groups from pre- to post-respirations chamber measurement, but the increase was less pronounced $(p<0.05$; Figure 3$)$ in the $\mathrm{HP} / \mathrm{MCHO}$ group compared to the $\mathrm{MP} / \mathrm{HCHO}$ group $(0.23 \pm 0.22 \mathrm{mmol} / \mathrm{L}$ versus $0.47 \pm 0.35 \mathrm{mmol} / \mathrm{L}$, respectively).

\subsection{Ad Libitum Energy Intake After Leaving the Chamber}

Ad libitum energy intake (EI) (EI; MP/HCHO: 30.6\% $\pm 10.4 \%$ energy requirement, $\mathrm{HP} / \mathrm{MCHO}$ : $33.5 \% \pm 12.4 \%$ energy requirement) as well as macronutrient content of meal choice (protein intake $\mathrm{MP} / \mathrm{HCHO}: 18.5 \% \pm 4.8 \%$ energy intake (\%EI), $\mathrm{HP} / \mathrm{MCHO}: 17.9 \% \pm 4.0 \% \mathrm{EI}$; carbohydrate intake $\mathrm{MP} / \mathrm{HCHO}: 50.2 \% \pm 8.1 \% \mathrm{EI}, \mathrm{HP} / \mathrm{MCHO}: 46.9 \% \pm 7.5 \% \mathrm{EI}$; fat intake MP/HCHO: $30.3 \% \pm 7.4 \%$ EI, HP/MCHO: $32.7 \% \pm 6.0 \% \mathrm{EI}$ ) assessed during ad libitum brunch were not different between intervention groups. Ad libitum energy intake was not associated with excursions of gut peptides the day before or by insulin resistance, but it was negatively associated with total glucose concentrations (iAUC) of the previous day $(r=-0.40, p<0.05)$.

\section{Discussion}

This study demonstrates that a 48 hour high-protein/moderate-carbohydrate diet fed in energy balance under controlled conditions, reduced the perception of hunger and increased 2-AG concentrations after 34 months in a post-obese condition, compared to a moderate-protein, highercarbohydrate diet. Hunger was inversely associated with PYY concentrations in the HP/MCHO group but not in the $\mathrm{MP} / \mathrm{HCHO}$ group. High-protein/moderate-carbohydrate intake led to a blunted increase in TAG compared to moderate-protein/high-carbohydrate intake, while changes in TAG were inversely associated with OAE.

Reduced hunger and increased satiety or fullness have been previously found in studies applying acute high-protein diets, even in negative energy balance $[13,14,25]$. The decrease in hunger in the $\mathrm{HP} / \mathrm{MCHO}$ versus the $\mathrm{MP} / \mathrm{HCHO}$ group in the current study, however, did not translate into a decreased energy intake in the ad libitum brunch. Rather large differences in appetite ratings (e.g., $\sim 40 \%$ ) were 
necessary to actually result in differences in energy intake of e.g., $20 \%$ in other studies, which applied a within subject design [8].

Among the endocannabinoids and related compounds studied, 2-AG showed a consistent meal-related pattern with highest concentrations one hour postprandially and lowest concentrations before the three meals. Interestingly, around all meals, the pattern of 2-AG concentrations was similar to that of concentrations in glucose, insulin, GLP-1, and PYY concentrations. However, in contrast to these parameters, 2-AG was the only one to be specifically affected by the higher-protein/moderate-carbohydrate content. Previous observations of plasma 2-AG dynamics around meals have been conflicting, from no meal-effect $[36,40]$ to increased concentrations only after a hedonic meal, in both normal weight individuals [41] and in obese [42]. These data suggest that if food intake is driven by palatability of the food presented, rather than hunger, an increase in circulating 2-AG concentrations is observed, independent of the individuals' BMI [41,42]. As higher 2-AG concentrations have been observed even before the actual consumption of palatable food, the authors have proposed an anticipatory role for this endocannabinoid in signaling the pleasure of the palatable food that is going to be eaten [41]. Regarding the possible hedonic component in endocannabinoid dynamics, desire to eat was not different between the intervention groups, and meals were described as equally pleasant in our study. However, postprandial changes in 2-AG were positively related to changes in pleasantness after dinner, therefore a hedonic effect cannot be excluded. No evidence can be found for a direct postprandial association of 2-AG with excursions of PYY and GLP-1 on an individual meal basis, suggesting a gut peptide-independent pathway of 2-AG in the current study. In contrast, 2-AG has been shown to be associated with GLP-1 [43] but not with appetite perception [41,43] previously. In the current study, however, postprandial changes of 2-AG were associated with changes in hunger after dinner. In our study, we characterized responses in participants who were still overweight, who had undergone a weight loss period for eight weeks followed by a 34 month period of weight maintenance before the current experiment was started. It is possible that the participants studied have a hedonic response different from lean, healthy-weight individuals, which in part may explain the postprandial increase in 2-AG concentrations observed in both intervention groups as 2-AG concentrations has been shown to be associated with BMI $[18,19]$. Finally, a likely origin of the changes in circulating 2-AG concentrations may be the intestine. Indeed, studies in rats have shown that gustatory stimulation with fat, without actual food intake, leads to an increase in both 2-AG and AEA content in the small intestine, which then further favor fat consumption through a positive feedback loop involving vagal afferents and the brainstem [44]. Accordingly, it has been shown that cheese with a specific fatty acid profile could influence plasma endocannabinoids in humans [45]. However, the role of other nutrients, especially protein on endocannabinoid concentrations, has never been studied before. To our knowledge, the current data are therefore the first evidence of a link between an increased protein/carbohydrate ratio and circulating 2-AG concentrations. Further research is needed to investigate the potential impact on weight loss and weight maintenance of this observation.

While AEA has been described as an orexigenic compound in the literature [20,36], PEA, OEA, and PREG were associated with anorexigenic effects [22,46-49]. OEA has been suggested to influence fat catabolism [50] and stimulate lipolysis [51]. While OEA was not associated with fat oxidation in the current study, the inverse relationship found between OEA and blunted TAG concentrations may be due to an increase in lipolysis.

In addition, in the present study, research participants were assessed in a controlled respiration chamber setting, and were fed in energy balance, which could overshadow the perception of hunger and satiety that people experience in a real-life situation. Finally, the fact that 2-AG and AEA behave differently should not be surprising, as they are synthetized through different pathways, which may further support a different role for the compounds in food intake regulation [52]. As for the origin of endocannabinoids and their related compounds, we and others have proposed that prandial-related changes in plasma AEA, 2-AG, OEA and PEA may primarily reflect changes in synthesis from the gastrointestinal tract [36]. 
Regarding the gut peptides, we found an inverse association between hunger and PYY concentrations in the HP/MCHO group only. PYY has previously been shown to be increased in response to a HP diet and was suggested to mediate the satiating effects of dietary protein [24]. Our data supports other literature proposing a 'threshold' level of protein to be necessary to exert effects on PYY-mediated impact on hunger [53,54]. PYY and GLP-1 concentrations have been linked to satiety and food intake [26], with rather weak associations [13]. GLP-1 release on the other hand has been primarily associated with dietary carbohydrates and fat and has been shown to be lower by high protein whilst satiety was increased compared to high carbohydrate [55]. Some evidence points to a stimulation of GLP-1 by a HP condition [56,57]. In comparison, PYY appeared to be stimulated by dietary protein content to a larger extent than GLP-1 [27,57]. However, changes in gut peptides by dietary protein content in the present study did not translate into changes in appetite perception. Relations between endogenous gut peptides and appetite ratings have shown hardly any, or conflicting results in the past [27], and have often been either absent [11], or weak [13]. Despite these discrepancies in subjective and objective appetite measures, appetite ratings by visual analogue scales have been shown to be highly reproducible [34] and may therefore still be important in assessing appetite next to physiologic measures. Taken together, the current study suggests that observed effects on 2-AG, hunger, and the association of PYY and hunger are nutrient-related, since they are especially shown in the $\mathrm{HP} / \mathrm{MCHO}$ group.

While changes in TAG concentrations were blunted in the high-protein/moderate-carbohydrate group, both intervention groups increased their TAG concentrations when comparing pre- and post-respiration chamber measurements. The general increase in TAG may be related to the sedentary circumstances the participants experienced throughout their $48 \mathrm{~h}$ stay $[58,59]$. High protein intake has previously been suggested to increase lipolysis [60] and inhibit lipogenesis [61], which may explain the blunted increase in TAG in the HP/MCHO condition compared to the $\mathrm{MP} / \mathrm{HCHO}$ condition in the current study.

The current study investigates the effects of a diet with higher protein and lower carbohydrate content compared to a diet with lower protein and higher carbohydrate content. Although there is some evidence describing the role of protein over carbohydrate on hunger perception [11], the current study design is not sufficient to clearly allocate the effect to one of the two macronutrients. To assign the described effects on 2-AG, hunger and PYY, and TAG, conclusively to a high protein or moderate carbohydrate level, or to a combination of both, longer follow-up studies are needed.

\section{Conclusions}

In conclusion, findings from the present study confirm that a higher dietary protein/carbohydrate ratio has appetite regulating effects. Additionally, it shows that 2-AG concentrations appear to be an important contributor to appetite related effects of a high- protein/moderate-carbohydrate diet, and that PYY may be one of the mediators in this increased protein/carbohydrate ratio-induced appetite regulation with an impact on reduced hunger perception, after 34 months in the post-obese phase.

Supplementary Materials: The following are available online at http://www.mdpi.com/2072-6643/11/10/2269/s1, Figure S1: Flow diagram of the study.

Author Contributions: Conceptualization, B.G.-C., M.S.W.-P., and T.C.A.; methodology, L.T., M.D., B.G.-C., M.S.W.-P., and T.C.A.; formal analysis, L.T., M.D., and T.C.A.; investigation, L.T., M.D., and B.G.-C.; data curation, L.T., M.D., B.H., and I.M.; writing-original draft preparation, L.T.; writing-review and editing, M.D., B.G.-C., A.R., M.F., B.H., J.J.H., I.M., D.C., R.P.M., P.J.J., M.S.W.-P., and T.C.A.; visualization, L.T.; supervision, R.P.M., P.J.J., M.S.W.-P., and T.C.A.; project administration, L.T. and M.D.; funding acquisition, A.S. and M.S.W.-P.

Funding: This research was funded by the EU seventh Framework Programme, grant number 312057 (FP7-KBBE-2012.2.2-03). DC and IM are supported by INSERM. The analytical chemistry platform at Neurocentre Magendie is supported through INSERM and Labex BRAIN ANR-10-LABX-43.

Acknowledgments: We would like to thank Wendy Sluijsmans, Hasibe Aydeniz, Maud Beckers, and Maurice Konings for the analysis of the samples, Georgina Balcells-Aribau for technical help with analysis of endocannabinoids and related compounds, and our participants for taking part in the study. 
Conflicts of Interest: The authors declare no conflict of interest. The funders had no role in the design of the study, in the collection, analyses, or interpretation of data, in the writing of the manuscript, or in the decision to publish the results.

\section{Abbreviations}

\begin{tabular}{|c|c|}
\hline 2-AG & 2-arachidonoylglycerol \\
\hline AEA & anandamide \\
\hline AUC & area under the curve \\
\hline BHB & $\beta$-hydroxybutyrate \\
\hline BMI & body mass index \\
\hline BMR & basal metabolic rate \\
\hline CB1 & cannabinoid receptor 1 \\
\hline CB2 & cannabinoid receptor 2 \\
\hline dAUC & decremental area under the curve \\
\hline EDTA & ethylenediaminetetraacetic acid \\
\hline EI & energy intake \\
\hline FFM & fat-free mass \\
\hline FM & fat mass \\
\hline GC-MS & gas chromatography-mass spectrometry \\
\hline GC-MS/MS & gas chromatography-tandem mass spectrometry \\
\hline GI & glycemic index \\
\hline GLP-1 & glucagon-like peptide-1 \\
\hline HOMA-IR & homeostatic model assessment for insulin resistance \\
\hline $\mathrm{HP} / \mathrm{MCHO}$ & high protein/ moderate carbohydrate \\
\hline iAUC & incremental area under the curve \\
\hline MJ & megajoule \\
\hline mmVAS & milimeter visiual analogue scale \\
\hline $\mathrm{MP} / \mathrm{HCHO}$ & moderate-protein/ high-carbohydrate \\
\hline OEA & oleoylethanolamide \\
\hline OGTT & oral glucose tolerance test \\
\hline PEA & palmitoylethanolamide \\
\hline PMSF & phenylmethylsulfonyl fluoride \\
\hline PREG & pregnenolone \\
\hline PYY & polypeptide YY \\
\hline TAG & triacylglycerol \\
\hline $\mathrm{T} 2 \mathrm{D}$ & type II diabetes \\
\hline VAS & visual analogue scale \\
\hline
\end{tabular}

\section{References}

1. World Health Organization. Global Health Observatory (GHO) Data. Available online: https://www.who. int/gho/ncd/risk_factors/overweight/en/ (accessed on 5 August 2019).

2. World Health Organization. Global Atlas on Cardiovascular Disease Prevention and Control; Shanti Mendis, P.P., Bo, N., Eds.; World Health Organization: Geneva, Switzerland, 2011; pp. 3-18.

3. Anderson, G.H.; Moore, S.E. Dietary proteins in the regulation of food intake and body weight in humans. J. Nutr. 2004, 134, 974S-979S. [CrossRef] [PubMed]

4. Astrup, A. The satiating power of protein-A key to obesity prevention? Am. J. Clin. Nutr 2005, 82, 1-2. [CrossRef] [PubMed]

5. Halton, T.L.; Hu, F.B. The effects of high protein diets on thermogenesis, satiety and weight loss: A critical review. J. Am. Coll. Nutr. 2004, 23, 373-385. [CrossRef] [PubMed]

6. Paddon-Jones, D.; Westman, E.; Mattes, R.D.; Wolfe, R.R.; Astrup, A.; Westerterp-Plantenga, M. Protein, weight management, and satiety. Am. J. Clin. Nutr. 2008, 87, 1558s-1561s. [CrossRef]

7. Reid, M.; Hetherington, M. Relative effects of carbohydrates and protein on satiety-A review of methodology. Neurosci. Biobehav. Rev. 1997, 21, 295-308. [CrossRef] 
8. Veldhorst, M.A.; Nieuwenhuizen, A.G.; Hochstenbach-Waelen, A.; Westerterp, K.R.; Engelen, M.P.; Brummer, R.J.; Deutz, N.E.; Westerterp-Plantenga, M.S. A breakfast with $\alpha$-lactalbumin, gelatin, or gelatin + TRP lowers energy intake at lunch compared with a breakfast with casein, soy, whey, or whey-GMP. Clin. Nutr. 2009, 28, 147-155. [CrossRef] [PubMed]

9. Martens, E.A.; Gonnissen, H.K.; Gatta-Cherifi, B.; Janssens, P.L.; Westerterp-Plantenga, M.S. Maintenance of energy expenditure on high-protein vs. high-carbohydrate diets at a constant body weight may prevent a positive energy balance. Clin. Nutr. 2015, 34, 968-975. [CrossRef]

10. Veldhorst, M.A.; Westerterp, K.R.; Westerterp-Plantenga, M.S. Gluconeogenesis and protein-induced satiety. Br. J. Nutr. 2012, 107, 595-600. [CrossRef]

11. Soenen, S.; Martens, E.A.; Hochstenbach-Waelen, A.; Lemmens, S.G.; Westerterp-Plantenga, M.S. Normal protein intake is required for body weight loss and weight maintenance, and elevated protein intake for additional preservation of resting energy expenditure and fat free mass. J. Nutr. 2013, 143, 591-596. [CrossRef]

12. Westerterp-Plantenga, M.S.; Lejeune, M.P.; Nijs, I.; van Ooijen, M.; Kovacs, E.M. High protein intake sustains weight maintenance after body weight loss in humans. Int. J. Obes. Relat. Metab. Disord. 2004, 28, 57-64. [CrossRef]

13. Lejeune, M.P.; Westerterp, K.R.; Adam, T.C.; Luscombe-Marsh, N.D.; Westerterp-Plantenga, M.S. Ghrelin and glucagon-like peptide 1 concentrations, 24-h satiety, and energy and substrate metabolism during a high-protein diet and measured in a respiration chamber. Am. J. Clin. Nutr. 2006, 83, 89-94. [CrossRef]

14. Westerterp-Plantenga, M.S.; Rolland, V.; Wilson, S.A.; Westerterp, K.R. Satiety related to 24 h diet-induced thermogenesis during high protein/carbohydrate vs high fat diets measured in a respiration chamber. Eur. J. Clin. Nutr. 1999, 53, 495-502. [CrossRef] [PubMed]

15. Mazier, W.; Saucisse, N.; Gatta-Cherifi, B.; Cota, D. The Endocannabinoid System: Pivotal Orchestrator of Obesity and Metabolic Disease. Trends Endocrinol. Metab. 2015, 26, 524-537. [CrossRef]

16. Silvestri, C.; Di Marzo, V. The endocannabinoid system in energy homeostasis and the etiopathology of metabolic disorders. Cell Metab. 2013, 17, 475-490. [CrossRef]

17. Simon, V.; Cota, D. Mechanisms in Endocrinology: Endocannabinoids and metabolism: Past, present and future. Eur. J. Endocrinol. 2017, 176, R309-R324. [CrossRef]

18. Bluher, M.; Engeli, S.; Kloting, N.; Berndt, J.; Fasshauer, M.; Batkai, S.; Pacher, P.; Schon, M.R.; Jordan, J.; Stumvoll, M. Dysregulation of the peripheral and adipose tissue endocannabinoid system in human abdominal obesity. Diabetes 2006, 55, 3053-3060. [CrossRef]

19. Cote, M.; Matias, I.; Lemieux, I.; Petrosino, S.; Almeras, N.; Despres, J.P.; Di Marzo, V. Circulating endocannabinoid levels, abdominal adiposity and related cardiometabolic risk factors in obese men. Int. J. Obes. 2007, 31, 692-699. [CrossRef]

20. Engeli, S.; Lehmann, A.C.; Kaminski, J.; Haas, V.; Janke, J.; Zoerner, A.A.; Luft, F.C.; Tsikas, D.; Jordan, J. Influence of dietary fat intake on the endocannabinoid system in lean and obese subjects. Obesity 2014, 22, E70-E76. [CrossRef]

21. Piomelli, D. A fatty gut feeling. Trends Endocrinol. Metab. 2013, 24, 332-341. [CrossRef]

22. Vallee, M.; Vitiello, S.; Bellocchio, L.; Hebert-Chatelain, E.; Monlezun, S.; Martin-Garcia, E.; Kasanetz, F.; Baillie, G.L.; Panin, F.; Cathala, A.; et al. Pregnenolone can protect the brain from cannabis intoxication. Science 2014, 343, 94-98. [CrossRef]

23. Pagotto, U.; Marsicano, G.; Cota, D.; Lutz, B.; Pasquali, R. The emerging role of the endocannabinoid system in endocrine regulation and energy balance. Endocr. Rev. 2006, 27, 73-100. [CrossRef]

24. Batterham, R.L.; Heffron, H.; Kapoor, S.; Chivers, J.E.; Chandarana, K.; Herzog, H.; Le Roux, C.W.; Thomas, E.L.; Bell, J.D.; Withers, D.J. Critical role for peptide YY in protein-mediated satiation and body-weight regulation. Cell Metab. 2006, 4, 223-233. [CrossRef]

25. Westerterp-Plantenga, M.S.; Lejeune, M.P.; Smeets, A.J.; Luscombe-Marsh, N.D. Sex differences in energy homeostatis following a diet relatively high in protein exchanged with carbohydrate, assessed in a respiration chamber in humans. Physiol. Behav. 2009, 97, 414-419. [CrossRef]

26. De Graaf, C.; Blom, W.A.; Smeets, P.A.; Stafleu, A.; Hendriks, H.F. Biomarkers of satiation and satiety. Am. J. Clin. Nutr. 2004, 79, 946-961. [CrossRef] 
27. Leidy, H.J.; Armstrong, C.L.; Tang, M.; Mattes, R.D.; Campbell, W.W. The influence of higher protein intake and greater eating frequency on appetite control in overweight and obese men. Obesity 2010, 18, 1725-1732. [CrossRef]

28. Lemmens, S.G.; Martens, E.A.; Kester, A.D.; Westerterp-Plantenga, M.S. Changes in gut hormone and glucose concentrations in relation to hunger and fullness. Am. J. Clin. Nutr. 2011, 94, 717-725. [CrossRef]

29. Fogelholm, M.; Larsen, T.M.; Westerterp-Plantenga, M.; Macdonald, I.; Martinez, J.A.; Boyadjieva, N.; Poppitt, S.; Schlicht, W.; Stratton, G.; Sundvall, J.; et al. Preview: Prevention of Diabetes through Lifestyle Intervention and Population Studies in Europe and around the World. Design, Methods, and Baseline Participant Description of an Adult Cohort Enrolled into a Three-Year Randomised Clinical Trial. Nutrients 2017, 9. [CrossRef]

30. Drummen, M.; Tischmann, L.; Gatta-Cherifi, B.; Fogelholm, M.; Raben, A.; Adam, T.C.; Westerterp-Plantenga, M. High versus moderate protein intake reduces adaptive thermogenesis and induces a negative energy balance during long-term weight loss maintenance-A preview study. Under Review. 2019.

31. Schoffelen, P.F.; Westerterp, K.R.; Saris, W.H.; Ten Hoor, F. A dual-respiration chamber system with automated calibration. J. Appl. Physiol. 1997, 83, 2064-2072. [CrossRef]

32. Weir, J.B. New methods for calculating metabolic rate with special reference to protein metabolism. J. Physiol. 1949, 109, 1-9. [CrossRef]

33. Hochstenbach-Waelen, A.; Westerterp-Plantenga, M.S.; Veldhorst, M.A.; Westerterp, K.R. Single-protein casein and gelatin diets affect energy expenditure similarly but substrate balance and appetite differently in adults. J. Nutr. 2009, 139, 2285-2292. [CrossRef]

34. Flint, A.; Raben, A.; Blundell, J.E.; Astrup, A. Reproducibility, power and validity of visual analogue scales in assessment of appetite sensations in single test meal studies. Int. J. Obes. Relat. Metab. Disord. 2000, 24, 38-48. [CrossRef]

35. Matthews, J.N.; Altman, D.G.; Campbell, M.J.; Royston, P. Analysis of serial measurements in medical research. BMJ 1990, 300, 230-235. [CrossRef]

36. Gatta-Cherifi, B.; Matias, I.; Vallee, M.; Tabarin, A.; Marsicano, G.; Piazza, P.V.; Cota, D. Simultaneous postprandial deregulation of the orexigenic endocannabinoid anandamide and the anorexigenic peptide YY in obesity. Int. J. Obes. 2012, 36, 880-885. [CrossRef]

37. Kingsley, P.J.; Marnett, L.J. LC-MS-MS analysis of neutral eicosanoids. Methods Enzymol. 2007, 433, 91-112. [CrossRef]

38. Orskov, C.; Rabenhoj, L.; Wettergren, A.; Kofod, H.; Holst, J.J. Tissue and plasma concentrations of amidated and glycine-extended glucagon-like peptide I in humans. Diabetes 1994, 43, 535-539. [CrossRef]

39. Levy, J.C.; Matthews, D.R.; Hermans, M.P. Correct homeostasis model assessment (HOMA) evaluation uses the computer program. Diabetes Care 1998, 21, 2191-2192. [CrossRef]

40. Matias, I.; Gonthier, M.P.; Orlando, P.; Martiadis, V.; De Petrocellis, L.; Cervino, C.; Petrosino, S.; Hoareau, L.; Festy, F.; Pasquali, R.; et al. Regulation, function, and dysregulation of endocannabinoids in models of adipose and $\beta$-pancreatic cells and in obesity and hyperglycemia. J. Clin. Endocrinol. Metab. 2006, 91, 3171-3180. [CrossRef]

41. Monteleone, P.; Piscitelli, F.; Scognamiglio, P.; Monteleone, A.M.; Canestrelli, B.; Di Marzo, V.; Maj, M. Hedonic eating is associated with increased peripheral levels of ghrelin and the endocannabinoid 2-arachidonoyl-glycerol in healthy humans: A pilot study. J. Clin. Endocrinol. Metab 2012, 97, E917-E924. [CrossRef]

42. Monteleone, A.M.; Di Marzo, V.; Monteleone, P.; Dalle Grave, R.; Aveta, T.; Ghoch, M.E.; Piscitelli, F.; Volpe, U.; Calugi, S.; Maj, M. Responses of peripheral endocannabinoids and endocannabinoid-related compounds to hedonic eating in obesity. Eur. J. Nutr. 2016, 55, 1799-1805. [CrossRef]

43. Rigamonti, A.E.; Piscitelli, F.; Aveta, T.; Agosti, F.; De Col, A.; Bini, S.; Cella, S.G.; Di Marzo, V.; Sartorio, A. Anticipatory and consummatory effects of (hedonic) chocolate intake are associated with increased circulating levels of the orexigenic peptide ghrelin and endocannabinoids in obese adults. Food Nutr. Res. 2015, 59, 29678. [CrossRef]

44. DiPatrizio, N.V.; Astarita, G.; Schwartz, G.; Li, X.; Piomelli, D. Endocannabinoid signal in the gut controls dietary fat intake. Proc. Natl. Acad. Sci. USA 2011, 108, 12904-12908. [CrossRef] 
45. Pintus, S.; Murru, E.; Carta, G.; Cordeddu, L.; Batetta, B.; Accossu, S.; Pistis, D.; Uda, S.; Elena Ghiani, M.; Mele, M.; et al. Sheep cheese naturally enriched in $\alpha$-linolenic, conjugated linoleic and vaccenic acids improves the lipid profile and reduces anandamide in the plasma of hypercholesterolaemic subjects. Br. J. Nutr. 2013, 109, 1453-1462. [CrossRef]

46. Hillard, C.J. Circulating Endocannabinoids: From Whence Do They Come and Where are They Going? Neuropsychopharmacology 2018, 43, 155-172. [CrossRef]

47. Rodriguez de Fonseca, F.; Navarro, M.; Gomez, R.; Escuredo, L.; Nava, F.; Fu, J.; Murillo-Rodriguez, E.; Giuffrida, A.; LoVerme, J.; Gaetani, S.; et al. An anorexic lipid mediator regulated by feeding. Nature 2001, 414, 209-212. [CrossRef]

48. Racz, B.; Duskova, M.; Vondra, K.; Sramkova, M.; Hill, M.; Starka, L. Daily profiles of steroid hormones and their metabolites related to food intake. Physiol. Res. 2015, 64, S219-S225.

49. Fu, J.; Gaetani, S.; Oveisi, F.; Lo Verme, J.; Serrano, A.; Rodriguez De Fonseca, F.; Rosengarth, A.; Luecke, H.; Di Giacomo, B.; Tarzia, G.; et al. Oleylethanolamide regulates feeding and body weight through activation of the nuclear receptor PPAR- $\alpha$. Nature 2003, 425, 90-93. [CrossRef]

50. Witkamp, R.F. The role of fatty acids and their endocannabinoid-like derivatives in the molecular regulation of appetite. Mol. Aspects Med. 2018, 64, 45-67. [CrossRef]

51. Guzman, M.; Lo Verme, J.; Fu, J.; Oveisi, F.; Blazquez, C.; Piomelli, D. Oleoylethanolamide stimulates lipolysis by activating the nuclear receptor peroxisome proliferator-activated receptor $\alpha$ (PPAR- $\alpha$ ). J. Biol. Chem. 2004, 279, 27849-27854. [CrossRef]

52. Gatta-Cherifi, B.; Cota, D. Endocannabinoids and Metabolic Disorders. Handb. Exp. Pharmacol. 2015, 231, 367-391. [CrossRef]

53. El Khoury, D.; El-Rassi, R.; Azar, S.; Hwalla, N. Postprandial ghrelin and PYY responses of male subjects on low carbohydrate meals to varied balancing proportions of proteins and fats. Eur. J. Nutr. 2010, 49, 493-500. [CrossRef]

54. Paddon-Jones, D.; Leidy, H. Dietary protein and muscle in older persons. Curr. Opin. Clin. Nutr. Metab. Care 2014, 17, 5-11. [CrossRef]

55. Smeets, A.J.; Soenen, S.; Luscombe-Marsh, N.D.; Ueland, O.; Westerterp-Plantenga, M.S. Energy expenditure, satiety, and plasma ghrelin, glucagon-like peptide 1, and peptide tyrosine-tyrosine concentrations following a single high-protein lunch. J. Nutr. 2008, 138, 698-702. [CrossRef]

56. Raben, A.; Agerholm-Larsen, L.; Flint, A.; Holst, J.J.; Astrup, A. Meals with similar energy densities but rich in protein, fat, carbohydrate, or alcohol have different effects on energy expenditure and substrate metabolism but not on appetite and energy intake. Am. J. Clin. Nutr. 2003, 77, 91-100. [CrossRef]

57. Van der Klaauw, A.A.; Keogh, J.M.; Henning, E.; Trowse, V.M.; Dhillo, W.S.; Ghatei, M.A.; Farooqi, I.S. High protein intake stimulates postprandial GLP1 and PYY release. Obesity 2013, 21, 1602-1607. [CrossRef]

58. Gennuso, K.P.; Gangnon, R.E.; Thraen-Borowski, K.M.; Colbert, L.H. Dose-response relationships between sedentary behaviour and the metabolic syndrome and its components. Diabetologia 2015, 58, 485-492. [CrossRef]

59. Henson, J.; Yates, T.; Biddle, S.J.; Edwardson, C.L.; Khunti, K.; Wilmot, E.G.; Gray, L.J.; Gorely, T.; Nimmo, M.A.; Davies, M.J. Associations of objectively measured sedentary behaviour and physical activity with markers of cardiometabolic health. Diabetologia 2013, 56, 1012-1020. [CrossRef]

60. Uebanso, T.; Taketani, Y.; Fukaya, M.; Sato, K.; Takei, Y.; Sato, T.; Sawada, N.; Amo, K.; Harada, N.; Arai, H.; et al. Hypocaloric high-protein diet improves fatty liver and hypertriglyceridemia in sucrose-fed obese rats via two pathways. Am. J. Physiol. Endocrinol. Metab. 2009, 297, E76-E84. [CrossRef]

61. Margolis, L.M.; Rivas, D.A.; Ezzyat, Y.; Gaffney-Stomberg, E.; Young, A.J.; McClung, J.P.; Fielding, R.A.; Pasiakos, S.M. Calorie Restricted High Protein Diets Downregulate Lipogenesis and Lower Intrahepatic Triglyceride Concentrations in Male Rats. Nutrients 2016, 8, 571. [CrossRef]

(C) 2019 by the authors. Licensee MDPI, Basel, Switzerland. This article is an open access article distributed under the terms and conditions of the Creative Commons Attribution (CC BY) license (http://creativecommons.org/licenses/by/4.0/). 